This article was downloaded by: [Computing \& Library Services, University of Huddersfield]

On: 05 October 2014, At: 23:28

Publisher: Taylor \& Francis

Informa Ltd Registered in England and Wales Registered Number: 1072954 Registered office: Mortimer House, 37-41 Mortimer Street, London W1T 3J H, UK

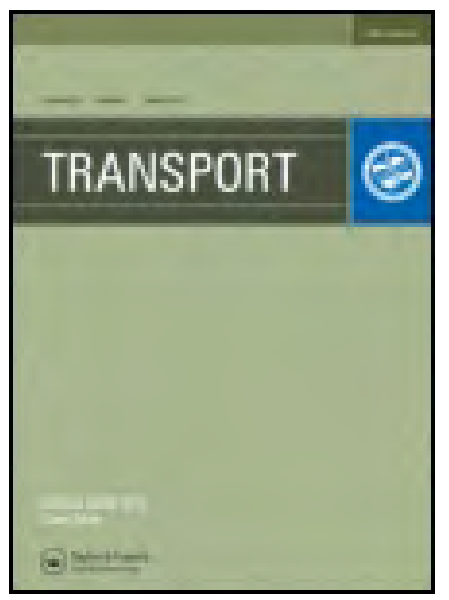

\title{
Transport
}

Publication details, including instructions for authors and subscription information: http:// www. tandfonline.com/loi/tran20

\section{Theoretical basis for an economic evaluation of road accident losses}

\author{
Denis Kapskij $^{\text {a }}$ \& Tatyana Samoilovich ${ }^{\text {b }}$ \\ a Belarusian National Technical University, 65 Nezavisimosti Avenue, Minsk, 220127, \\ Republic of Belarus E-mail: \\ ${ }^{b}$ Belarusian National Technical University, 65 Nezavisimosti Avenue, Minsk, 220127, \\ Republic of Belarus \\ Published online: 27 Oct 2010.
}

To cite this article: Denis Kapskij \& Tatyana Samoilovich (2009) Theoretical basis for an economic evaluation of road accident losses, Transport, 24:3, 200-204

To link to this article: http:// dx. doi.org/ 10.3846/ 1648-4142.2009.24. 200-204

\section{PLEASE SCROLL DOWN FOR ARTICLE}

Taylor \& Francis makes every effort to ensure the accuracy of all the information (the "Content") contained in the publications on our platform. However, Taylor \& Francis, our agents, and our licensors make no representations or warranties whatsoever as to the accuracy, completeness, or suitability for any purpose of the Content. Any opinions and views expressed in this publication are the opinions and views of the authors, and are not the views of or endorsed by Taylor \& Francis. The accuracy of the Content should not be relied upon and should be independently verified with primary sources of information. Taylor and Francis shall not be liable for any losses, actions, claims, proceedings, demands, costs, expenses, damages, and other liabilities whatsoever or howsoever caused arising directly or indirectly in connection with, in relation to or arising out of the use of the Content.

This article may be used for research, teaching, and private study purposes. Any substantial or systematic reproduction, redistribution, reselling, loan, sub-licensing, systematic supply, or distribution in any form to anyone is expressly forbidden. Terms \& Conditions of access and use can be found at http:// www.tandfonline.com/page/terms-and-conditions 


\title{
THEORETICAL BASIS FOR AN ECONOMIC EVALUATION OF ROAD ACCIDENT LOSSES
}

\author{
Denis Kapskij, Tatyana Samoilovich \\ Belarusian National Technical University, 65 Nezavisimosti Avenue, \\ 220127 Minsk, Republic of Belarus \\ E-mail: oapdd@bntu.by
}

Received 22 November 2008; accepted 3 September 2009

\begin{abstract}
The article regards the theoretical basis for estimating life value for the purpose of calculating road accident losses. The paper presents a simple structure of accident costs that could be taken into account in order to calculate the total economic value of road accidents. The article also shows the basic methods of estimating life value in different countries for different purposes and describes the problems of estimating life value in the Republic of Belarus. The paper comprises practically used values of life and the costs of injuries in some countries. Losses and costs caused by a road accident are regarded as direct and indirect. Besides, losses occurring during a road accident are considered as economic and social. The temporary estimated values of the total economic value of road accidents are discussed at the end of the article.
\end{abstract}

Keywords: road accident, accident costs, estimating life value, direct costs, indirect costs, economic constituent, social constituent, liability insurance.

\section{Introduction}

To define the economic wealthiness of a country, it is essential to take in account a fact that man is the central part of any economic system. A person brings income for a country in different areas of activity. That is why the loss of human abilities for work causes the reduction of the economic wealthiness of that country and generates soul pain of his relatives (Žvirblis and Zinkevičiūte 2008; Partheeban et al. 2008; Obelenis and Gedgaudiené 2003).

However, every area of national economy has its own risk of fatality. Thus, for example, a housewife, a car driver and a passenger of an airplane have different risks of fatality in their environments (house, road, aviation). A person can undergo such risk constantly as an employee in such environment (car driver) or accept such risk by necessity (passenger of an airplane).

Almost everyone in the world is getting a participant of road movement daily. As a result, it is $1.3 \%$ of deaths in the world caused by road accidents (Педен и др. 2004). The purpose of the article is to regard the basic methods of estimating life value used in different countries for different areas of economy and to define the peculiarities of estimating health or life damage that occurs during a road accident.

\section{Review of Methods Estimating Life Value}

The following methods can be introduced:

1. The method of life evaluation by calculation (basic). It takes into account such factors as an educational level of a person, his health, age, real income etc. On the basis of this data, it is calculated how much money a person could earn in the future for a definite period (not-received production, loss of net national income, loss of net national product, payment for sick-leave certificate, serving the injured in hospital, loss of work-time, medical costs, disability pensions, sick benefits etc.). The value received shows the value of life. This method is generally used by insurance companies and some state structures that preliminary determine the sum of compensation in cases a public officer dies on duty.

2. The method of life evaluation from the point of view of a person undergone to the risk of fatality. Practically used method appeared in 1963 and 1965. Prerequisite to its appearance was the fact that along with the development of the UK and USA, the compensations assigned by courts for accidents exceeded considerably discounted salary that could be obtained by a person during his/ 
her life (Бондарь и Вырожемский 2007). The method given is based on the analysis of apparent or hidden economy and related to the physically safe (unsafe) behaviour of people united by general purpose, spirit or actions. The method is based on the level of sums people are going to pay to save their lives, for example, the behavior of people in road movement, the amount of people who prefer air transport to the other safer kind of transport, compensation money for a dangerous job etc. Such method allows defining the monetary value of life for definite situations with further costs substantiation allotted to provide safety to people in these definite situations (road traffic, air transport, dangerous profession etc.). For instance, some devise of a definite price is possible to enlarge the definite sizes of the level of people safety. For example, the brakes of a new construction priced at $\$ 600$ are possible to reduce the braking distance of a vehicle and to reduce the possibility of accident with fatalities. Suppose the probability of driver's or passenger's fatality caused by road accident is 1 to 100000 . Consequently, if a driver agrees to provide his car with new brakes, s/he assesses his/her life in $\$ 60$ billions.

3. The assessment of personal life (public inquiry).

4. The method based on medical criteria (costs of members of the body, cost of treatment etc.).

In 1997, Australian scientist Paul Miller assessed the life of a person who died during an accident in 11-19 USD billions. Miller based his assessment on accounting compensations paid to the family of the dead person plus unpaid taxes, non-produced goods, not born children etc. (Страхование в Израиле 2009). Thus, the richer is the country the higher is life value. The most popular estimation of life value is based on the first method.

\section{Estimating Life Value in the Republic of Belarus}

At present, in the Republic of Belarus, the method of life evaluation is used when one needs to determine insurance money:

- for compulsory road carrier's liability insurance in public transport,

- for compulsory driver's liability insurance,

- for employers' compulsory liability insurance,

- for compulsory medical insurance of foreigners or stateless people temporarily living in the Republic of Belarus.

The value of life is defined in general for money payments that is why in order to reduce conflicts, it is convenient to evaluate life depending on the salary level and age of the injured person according to: 1) the rules of defining damage size caused to the life or health of the injured person during a road accident for the purposes of compulsory driver's liability insurance; 2) regulation of the procedure and conditions of driver's compulsory liability insurance introduced by the Decree of the Presi- dent of the Republic of Belarus dd. 19.02.1999 \#100, 3; 3) Decree of the President of the Republic of Belarus \# 531 About defining insurance rates, insurance premium and liability limits on some kinds of compulsory insurance.

It is apparent that such evaluation is not correct because only partial use is taken into account and could be made by the given person as producing some goods or making some job; moreover, the moral damage and suffering of relatives are not being taken into account (social constituent). It is turned out that loss caused by the death of the injured is less than that caused by injuries.

\section{Estimating Life Value of a Person Injured During a Road Accident}

The data obtained from different countries shows that road accident costs worsen the economic wealthiness of any country. Suffice it to say that the average age of road accident victims is about $20-40$ years old, i.e. they are people of the most productive age. Investigations conducted in Europe show that at a rough estimate accident, costs are not less than 2\% of the Gross Domestic Product (GDP) in average.

In the EU, road accidents cause in average 123 deaths daily. The amount fatalities caused by road accidents is almost 45 thousand annually and 1.6 million of people get injures that must be treated for a long time.

'Direct' annual costs related to road accident consequences account about 15 billion EUR including the treatment of injured people, work of road police and ambulance, repairing vehicles and road equipments etc.

Besides, 30 billion EUR are indirect accident costs in the EU because of the not-received value of goods and services production that could be produced by the union members that had died or been injured during road accidents.

For the first time, the losses of road accidents expressed in money were evaluated in the United Kingdom and USA in 1950. The estimation of the costs of the union was based on the method defining the cost of not-received production and services, thus costs were valued as the cost of production and services that were not received because of fatality or obtaining disability by the injured people during a road accident, treatment expenses and expenses for repairing vehicle and road equipment.

Accident costs can be expressed in different shapes. Fig. 1 shows a simple structure of accident costs.

Considering its character, the loss that occurred during a road accident consists of two constituents material (or economic) and spiritual (or social). The economic constituent consists of direct and indirect loses. Direct losses - are the losses of road damages, vehicles and goods damages, expenses on accident investigation, pensions, sick benefits, injured treatment and the funeral of died people.

Indirect losses are those of the Gross Domestic Product and of the temporary, partial or full exclusion of society members from production as well as the losses of road movement failure during an accident. 


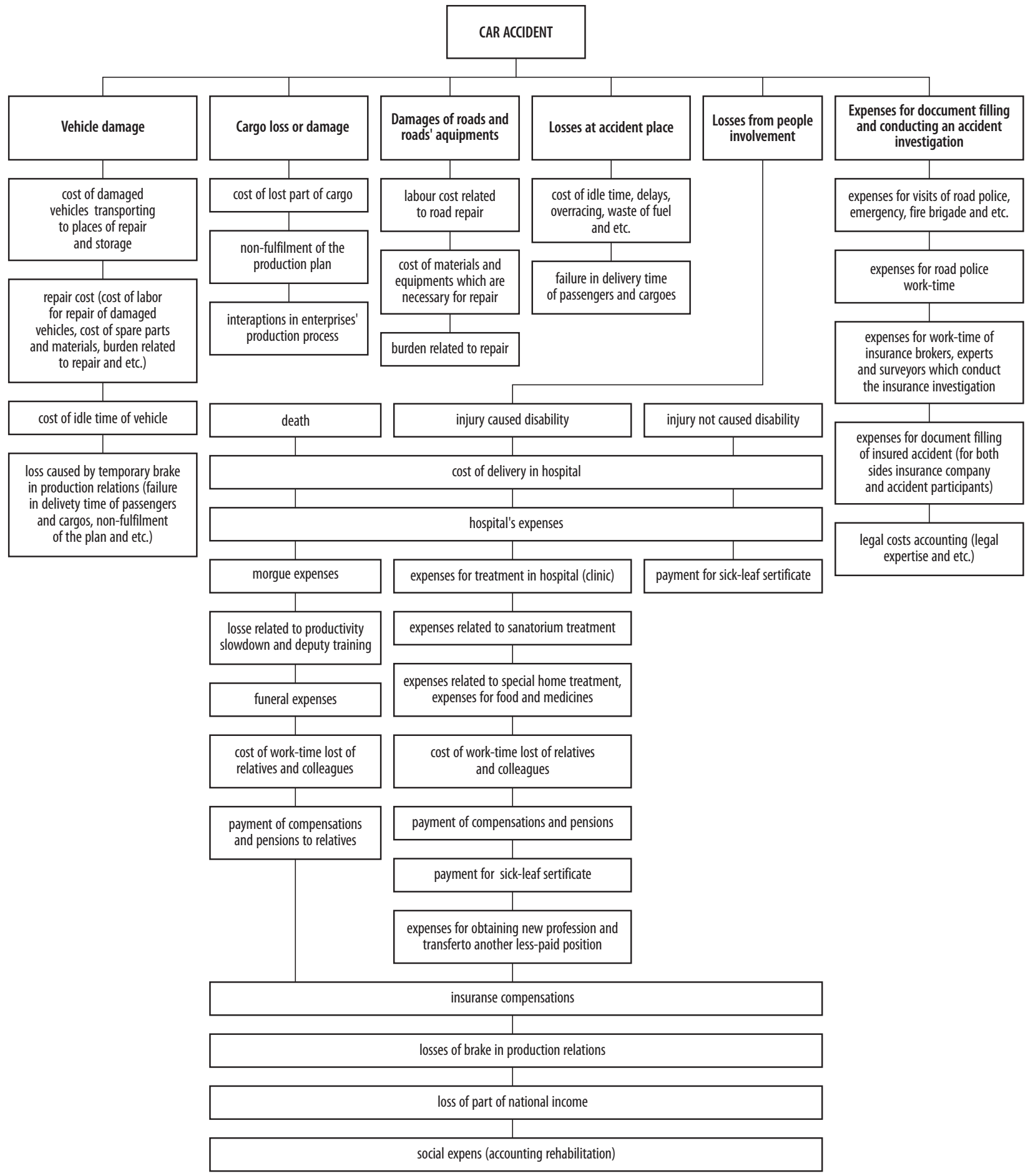

Fig. 1. The structure of the road accident costs (Врубель и др. 2006)

The social constituent includes the so-called 'soul pain' from the deaths or injuries of people including relatives etc. It also embraces the losses of people having normal psychic capacities and those exposed to the risk of fatality or the psychic of people exposed their relatives to the risk of fatality. Besides, it comprises the losses of plan collapse because of an accident or changes in a usual family's way of life. At last, it expresses 'social pain' because of the senseless loss of people. It should be noted that accidents take the best part of society the average age of which is about 33 years old and almost $80 \%$ of them are male. The same correlation can be noticed in the category of the injured people. It is impossible to directly value the social constituent. However, there were found some ways of valuing this constituent covering insurance, material compensation of moral damage by courts, norms taking into account the social constituent, public morals that allow or encourage definite practice etc. 
Table 1. Detailed indicators of loss cost caused by a road accident including a type of injury (AIS) (Draft TS... 2006; Breen 2004)

Detailed indicators of loss cost caused by a road accident including a type of injury (AIS)

\begin{tabular}{|c|c|c|}
\hline Weight index & Weight of consequences & Cost, US dollars \\
\hline AIS 6 & Death & 2600000 \\
\hline AIS 5 & Critical, grievous bodily harm & 1980000 \\
\hline AIS 4 & Serious, bodily harm of middle weight, possible health deterioration & 490000 \\
\hline AIS 3 & Serious, bodily harm of middle weight & 150000 \\
\hline AIS 2 & Bodily harm of middle weight, trivial injury, appeals & 40000 \\
\hline AIS 1 & Light bodily harm, trivial injury that are not included in state statistic reporting & 5000 \\
\hline
\end{tabular}

In the developed countries, insurance money is large, for example in the USA, insurance money for a road accident with the dead exceeds 2.5 billion USD, in Germany - exceeds 1.2 billion EUR, in Russia about 90000 USD (2 200000 RUR (Методика оценки и расчета ... 2001)) etc. It is exactly these amounts are included in the total assessed value of the accident. Our insurance only starts to be developed and the social constituent is not included in the total assessed value of the accident, and therefore nowhere is being accounted.

In the USA, detail loss indexes are developed and helps with defining accident cost according to the different weight of consequences (Table 1) (Draft TS ... 2006).

One of the information sources determining damage caused by a road accident is data on insurance payments covering compulsory driver's liability insurance (see Table 2). The average insurance money for one insured accident in 2008 in Minsk was 1630000 BYR (740 USD). This indicator is lower than that in other regional cities (for instance, in Bobruisk, this amount is 192600 BYR). Insurance money characterizes damage that occurred during a road accident without accounting the lost value of commodity, lost profit or moral damage.

\section{Estimating Life Value of a Person Injured During a Road Accident in the Republic of Belarus}

According to Rules for defining the size of damage caused by death or life during a road accident, for the purposes of compulsory driver's liability insurance, damage caused by death or injury occurring during a road accident must be compensated without taking into account the barratry of the injured person or the absence of the fault of tortfeasor. Defining disability rate and disability group is performed by the rehabilitation commission making a conclusion on the necessity of additional compensations for damage. The injured person is refunded additional expenses caused by the injury occurred during a road accident taking into account treatment expenses, additional meal, medication acquisition, prosthetics, nursing, sanatorium treatment, special vehicles acquisition, retraining courses for obtaining new profession in case it is determined that the injured person needs such kinds of render assistance and treatment and has no possibility of getting it for free. The additional expenses of the injured person caused by health damage (excluding treatment and medication expenses) must be paid on the basis of the claim and conclusion of the rehabilitation commission on the necessity.

According to p. 35 of Regulation on the procedure and conditions of driver's compulsory liability insurance, insurance money must cover material damage caused by death, injury or other body damage, health loss or damage, property loss or damage accounting roads, road equipments, traffic lights, signs and other objects. Moral damage, lost profit and the loss of the value of commodity are not subjects to compensation.

Table 2. Data on the average amounts of insurance money according to the living place of a person guilty of a road accident (2008, compulsory driver's liability insurance

(Основные показатели работы... 2009))

\begin{tabular}{|c|c|}
\hline City & $\begin{array}{c}\text { Average amounts of insurance money, } \\
\text { thousand of rubles }\end{array}$ \\
\hline Minsk & 1630 \\
\hline Mogilev & 1641.4 \\
\hline Grodno & 1578.5 \\
\hline Brest & 1468 \\
\hline Gomel & 1353.1 \\
\hline Vitebsk & 1253.2 \\
\hline Bobruisk & 1926.3 \\
\hline Baranovichi & 1889.2 \\
\hline Zhodino & 1652.8 \\
\hline Pinsk & 1633.1 \\
\hline Soligorsk & 1575.5 \\
\hline Novopolotsk & 1528.7 \\
\hline Kobrin & 1501.3 \\
\hline Mozyr & 1493.8 \\
\hline Rechitsa & 1490.8 \\
\hline Lida & 1466.1 \\
\hline Borisov & 1459.3 \\
\hline Slonim & 1438.2 \\
\hline Zhlobin & 1427.8 \\
\hline Orsha & 1408.6 \\
\hline Slutsk & 1393.2 \\
\hline Svetlogorsk & 1236.5 \\
\hline Molodechno & 1179.5 \\
\hline Polotsk & 1173.2 \\
\hline Others & 1629.1 \\
\hline
\end{tabular}


According to the Decree of the President of the Republic of Belarus \#531 About defining insurance rates, insurance premium and liability limits on some kinds of compulsory insurance, maximum liability limits to injury or life damage reach 10000 EUR and to the property of the injured people - 10000 EUR. Thus, the total amount of insurance coverage limit must not exceed 20000 Euro. If the occurred damage exceeds these limits, difference is being judicially recovered by a guilty driver.

In case of the death of the injured person caused by the accident, actually paid necessary expenses on funeral are objects to compensation. These expenses are limited by 500 EUR for acquiring and placing gravestone, equipping a burial place and 400 EUR for funeral and funeral repast.

In the Republic of Belarus, the method based on income is also used.

\section{Conclusions}

Taking into account premises, we can draw the following conclusion:

Until more grounded data will be obtained in the Republic of Belarus, it is recommended to use data presented in Table 3.

Table 3. The recommended (temporary) estimated values of the total economic value of road accidents

\begin{tabular}{|c|c|c|}
\hline \multicolumn{2}{|c|}{ Weight of consequences } & Cost, c.u. \\
\hline \multicolumn{2}{|l|}{ Death } & 90000 \\
\hline \multicolumn{2}{|c|}{ Injury, caused disability } & 30000 \\
\hline \multicolumn{2}{|c|}{ Grievous bodily harm } & 3800 \\
\hline \multicolumn{2}{|c|}{ Light bodily harm } & 1900 \\
\hline \multicolumn{2}{|c|}{ Material damage } & 750 \\
\hline \multirow{3}{*}{$\begin{array}{c}\text { Average } \\
\text { values }\end{array}$} & $\begin{array}{l}\text { Accident without } \\
\text { consequences weight provided }\end{array}$ & 3100 \\
\hline & Accident with injured people & 14000 \\
\hline & Accident with injury & 2600 \\
\hline
\end{tabular}

\section{References}

Breen, J. 2004. Road safety advocacy, British Medical Journal 328(7444): 888-890. doi:10.1136/bmj.328.7444.888.

Draft TS measure assessment Guidelines for STP_3005 2006.

Obelenis, V.; Gedgaudienè, D. 2003. Study on occupational and nonoccupational risk factors and health of motor transport workers, Transport 18(4): 189-192.

Partheeban, P.; Arunbab, E.; Hemamalini, R. R. 2008. Road accident cost prediction model using systems dynamics approach, Transport 23(1): 59-66. doi:10.3846/1648-4142.2008.23.59-66.

TDM Encyclopedia. 2008. Evaluating Safety and Health Impacts. TDM Impacts on Traffic Safety, Personal Security and Public Health. Victoria Transport Policy Institute. Available from Internet: <http://www.vtpi.org/tdm/tdm58. htm\#_Toc65190623>.
Žvirblis, A.; Zinkevičiūtè, V. 2008. The integrated evaluation of the macro environment of companies providing transport services, Transport 23(3): 266-272. doi:10.3846/1648-4142.2008.23.266-272.

Аналитический сборник по аварийности [Analytical Proceedings on Traffic Accidents]. 2008. Минск: Полиграфический центр МВД Республики Беларусь. 81 с. (in Russian).

Бондарь, Т. В.; Вырожемский, В. К. 2007. Аварийность на дорогах Украины, в кн: Материаль 5-й международной научно-технической конферениии «Наука - образованию, производству, экономике» [Bondar, T. V.; Vyrozhemskij, V. K. Traffic Accidents on Roads of Ukraine, in: Proceedings of 5th International Scientific and Technical Conference 'Science - for Education, Industry and Economics']. Минск, БНТУ, 1: 546-554 (in Russian).

Врубель, Ю. А.; Капский, Д. В.; Кот, Е. Н. 2006. Определение потерь в дорожном движении [Vrubel, J. A.; Kapskij, D. V.; Kot, E. N. Defining Road Accident Losses]. Минск: БНТУ. 252 c. (in Russian).

Методика оценки и расчета нормативов социальноэкономического ущерба от дорожно-транспортных происшествий Р-03112199-0502-00: Трансконсалтинг. [Methods of Estimating and Calculating Specifications of Social and Economic Losses on Road and Transport Accidents P-03112199-0502-00: Trans Consulting] 2001. Москва. 57 с. Available from Internet: <http://www. complexdoc.ru/ntdpdf/547052/metodika_otsenki_i_ rascheta_normativov_sotsialno-ekonomicheskogo_ ushcherba.pdf $>$. (in Russian).

Основные показатели работы по проведению обязательного страхования гражданской ответственности владельиев транспортных средств в Республике Беларусь за 2008 год [The Basic Indicators of Work on Carrying Out Oligatory Civil Liability Insurance of the Owners of Vehicles in Byelorussia in 2008]. 2009. Минск: Белорусское бюро по транспортному страхованию. 77 с.

Педен, М.; Скарфилд, Р.; Слит, Д.; Мохан, Д.; Хайдер, Э. А.; Джараван, Э.; Мазер, К. 2004. Всемирный доклад о предупреждении дорожно-транспортного травматизма [Peden, M.; Scurfield, R.; Sleet, D.; Mohan, D.; Hyder, A. A.; Jarawan, E.; Mathers, C. World Report on Road Traffic Injury Prevention]. Москва: Весь Мир. 280 с. Available from Internet: <http://www.who.int/publications/ list/9241562609/ru/index.html>. (in Russian).

Страхование в Израиле [Insurance in Israel]. 2009. Available from Internet: <http://www.insuranceisrael.com/news/na stoimost_chelovecheskoi_zhizni_net_edinogo_tarifa.html> (in Russian).

Филистович, В. Л. 2007. Аналитический сборник: Справочно-информационные материалы «Состояние безопасности дорожного движения в Республике Беларусь в 1999-2006 годах и наметившиеся тендениии» [Filistovič, V. L. Analytical Proceedings: Traffic Safety Status and Projected Tendencies in the Republic of Belarus in 1999-2006]. Минск: Полиграфический центр МВД Республики Беларусь. 124 c. (in Russian). 